
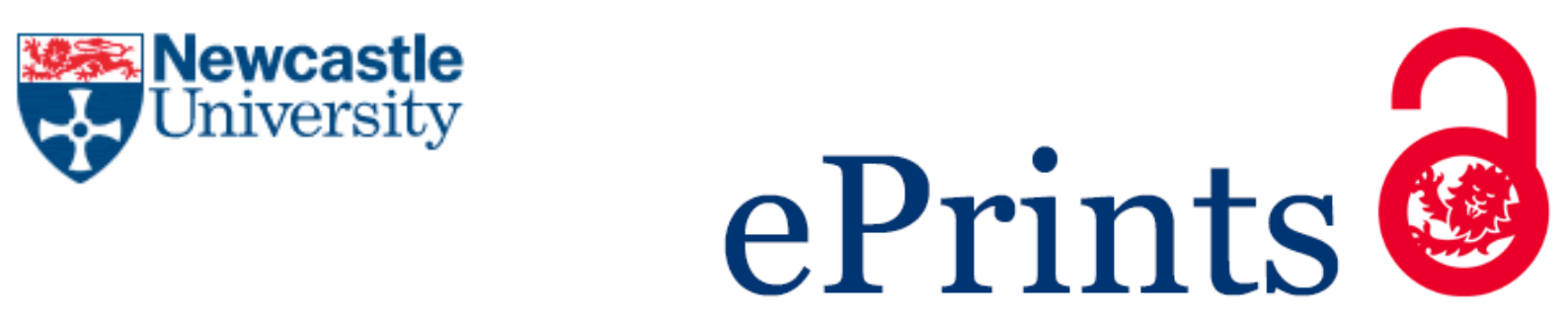

Whittle A, Suhomlinova O, Mueller F. Dialogue and distributed agency in institutional transmission. Journal of Management and Organization 2011, 17(4), 548-569.

\title{
Copyright:
}

This is the authors' accepted manuscript of an article published in its final form by Cambridge University Press, 2011

DOI link to article:

http://dx.doi.org/10.5172/jmo.2011.17.4.548

Date deposited:

$12 / 05 / 2015$

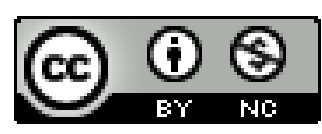

This work is licensed under a Creative Commons Attribution-NonCommercial 3.0 Unported License 
This is the author(s) personal version of the manuscript, as accepted after the review process but prior to final layout and copyediting by the publisher. The final version is published as:

Whittle, A., Suhomlinova, O. \& Mueller, F. (2011) Dialogue and Distributed Agency in Institutional Transmission. Journal of Management and Organization 17(4): 548-569.

Readers are kindly asked to use the official publication in references.

\title{
DIALOGUE AND DISTRIBUTED AGENCY IN INSTITUTIONAL TRANSMISSION
}

\begin{abstract}
In this paper we contribute to the body of work on agency and institutional transmission by proposing two new concepts: distributed agency and dialogue. 'Distributed agency' is a companion concept to “institutional entrepreneurship”. Whilst institutional entrepreneurship emphasizes the deliberate institution-building by a select few, distributed agency highlights the emergent institution-building that involves all organizational members. In turn, ‘dialogue’ supplements the models of institutional diffusion by drawing attention to the situated interactions between the "champions" and the "recipients" of institutional innovations. We analyze the micro-discursive processes during a crucial event in the institutionalization of a new organizational template in a UK public-private partnership. We found that institutional transmission hinged upon enabling the recipients to act as agents (hence, distributed agency) through dialogue around the audience's identity, interests and local concerns vis-à-vis coercive institutional pressures.
\end{abstract}

KEY WORDS Dialogue, Discourse, Distributed Agency, Institutional theory, Institutional entrepreneurship. 


\section{DIALOGUE AND DISTRIBUTED AGENCY IN INSTITUTIONAL TRANSMISSION}

This paper is about the "institutional work" (Lawrence \& Suddaby 2006) involved in the implementation of an institutional innovation. We ask: How does an institutional innovation become accepted by organizational members? In general terms, our query points to an important step in the process of institutionalization, located in Berger and Luckmann's (1967) scheme between objectivation and internalization. To answer this question, we introduce two contributions to the established model of institutional transmission. Firstly, we broaden the interpretation of institutional agency beyond the institutional entrepreneur to include, potentially, each and every organizational member. To initiate and promote an institutional innovation requires an institutional entrepreneur, but to embed it in and turn it into a taken-for-granted element of organizational reality, we suggest, calls for the participation of all actors expected to enact the innovation. To capture this collective property of institutionalization, we offer the term 'distributed agency'. Secondly, we contribute to the understanding of institutional transmission by highlighting the role of "interpreters" in modifying the innovation in dialogue with its recipients. Constructing "buy in" on the part of recipients, we suggest, requires engaging in a dialogue that re-constructs the innovation as congruent with the audience's interests, identity and local conditions. To reflect this relational/interactive property of institutionalization, we employ the notion of 'dialogue'. In our theorizing we build on the literatures on institutional work, distributed organizational phenomena (e.g., distributed cognition, distributed leadership) and dialogical organizational processes (e.g., dialogical learning).

To explore the role of distributed agency and dialogue, we take an empirical case of the introduction of a new template in a single organization, a public-private partnership located in the United Kingdom that delivers employment services to job seekers in areas of high unemployment. From a macro perspective, our case is a classic example of coercive isomorphism - the imposition of an organizational practice by a powerful institutional actor - since the new template was introduced under pressure from the contractor, the UK government's Department for Work and Pension, to improve the quality of the data 
supplied to the Department. We, however, concentrate on the micro-processes involved in the implementation of the new template in order to uncover what went on "under the surface" of acquiescence to the official mandate. In so doing we respond to calls for institutional theorists to 'increase the magnification of their research microscopes’ (Elsbach 2002: 54-55) and develop ‘a more micro and fieldwork tradition' (Palmer \& Biggart 2002: 276) in order to attend to the 'actors who give meaning and life to institutions' (Dacin, Goodstein \& Scott 2002: 47). As our case deals with the introduction of a quality initiative, the study also speaks to the issues of retention and customized application raised, respectively, by Zbaracki (1998: 612, 621-626) and David and Strang (2006: 230) in their analyzes of the implementation of total quality management programs.

Our analysis focuses on one crucial event - a training session intended to familiarize the employees with the new information system designed to support the data quality requirements. We examine the discursive interactions between the trainers responsible for implementing the new information system and their audience, i.e. the organizational members who are expected to enact the new quality template. Our analysis shows that, even though the innovation had already been sanctioned by a powerful institutional actor and translated into the language of the focal organization, its implementation was by no means a fait accompli, but required the concerted efforts of the trainers and their audience to make the innovation palatable and acceptable. Our analysis of the dialogue between the trainers and the audience shows that achieving "buy-in” requires investing the recipients of an innovation with agentic qualities. We distinguish three forms of agency present in the dialogue that allowed the recipients to be agents rather than “mere pawns”: (1) defining their identity vis-à-vis coercive pressures, (2) articulating their interests, and (3) recognizing their rights to do things "their way". The outcome of this dialogue is, we suggest, a reinterpreted and modified institutional template that facilitates, rather than hinders, the transmission of the innovation.

The paper is structured as follows: firstly, in the next section we elaborate our theoretical points of departure and subsequently, the third section presents our empirical case and embeds it into a broader institutional context. The fourth section outlines the methodology employed in the study. In the fifth 
section we present the analysis of the empirical material. Finally, we discuss our findings and consider the implications of our work for theory development.

\section{AGENCY AND INSTITUTIONAL TRANSMISSION}

The question of how to understand the transmission of institutions across time and space, and the role of agency in this process, has been central to institutional theory since its inception and remains contested to this date. The so-called old institutionalism, associated with the works of Selznick (1949), Gouldner (1954), and Zald (1970), has been commonly portrayed (occasionally in caricature) as a primarily actionoriented perspective, focusing on intra-organizational processes, dynamics, endogenous change, values and conflict of interests (DiMaggio \& Powell 1991: 13; Hirsch \& Lounsbury 1997: 408). The old institutionalism interpreted institutionalization as a bottom-up process, wherein agents are given a primary role in creating and shaping institutions, which paid little attention to the issue of institutional transmission across organizations. In contrast, the new institutionalism, launched by Meyer and Rowan's (1977) and DiMaggio and Powell’s (1983) seminal articles (DiMaggio \& Powell 1991), has been widely credited with redirecting attention to structure and moving towards a higher level of analysis by highlighting the dominance of the environment, stressing organizational stability and inertia, and adopting a cognitive approach to institutions (i.e., examining taken-for-granted beliefs and shared meanings) (DiMaggio \& Powell 1991: Hirsch \& Lounsbury 1997; Scott 2001: 83-88). The new institutionalism offered a sophisticated model of institutional diffusion by delineating three key mechanisms of institutional isomorphism: coercive (stemming “from political influence and the problem of legitimacy”), mimetic ("resulting from standard responses to uncertainty") and normative ("associated with professionalization”) (DiMaggio \& Powell 1983: 150). This model in turn generated extensive empirical research on diffusion (cf. Strang and Soule (1988) for review) and the forces of isomorphism (cf. Mizruchi and Fein (1999) for review and Heugens and Lander (2007) for meta-analysis of findings). The new institutionalism, however, downplayed the role of agency (DiMaggio 1988: 3,; DiMaggio \& Powell 
1991: 22) and portrayed institutionalization as a predominantly top-down imposition of institutionalized patterns on overly constrained organizations (Oliver 1991: 147-148).

In response to the extensive critique of the new institutionalism for its lack of attention to agency (e.g., Hirsch 1997, Hirsch \& Lounsbury 1997; Selznick 1996; Stinchcombe 1997), a "third-wave” of institutional theory (for want of a better term) has emerged, described as 'the coming together of the old and the new institutionalism' (Greenwood \& Hinings 1996: 1023). The third-wave institutionalism focuses on the institutional work that underlies the process of institution-building (Lawrence \& Suddaby 2006). This approach reconciles the action and structure orientations of the old and new institutionalism (e.g., Barley \& Tolbert 1997; Hasselbladh \& Kallinikos 2000) and enables us to explore 'the effects of individual and organizational action ... aimed at creating, maintaining, and disrupting institutions' (Lawrence \& Suddaby 2006: 216). This third-wave institutionalism has greatly advanced our understanding of agency and institutionalization. Yet, it has some limitations, of which we note two: a narrow locus of agency and an incomplete description of the process of institutional transmission.

To date, institutional research has tended to view agency as 'attributed either to an organization as a whole (Goodstein 1994; Oliver 1991) or to individuals who occupy central roles in an organization (Brint \& Karabel 1991; Zucker \& Darby 1997)' (Zilber 2002: 236). Agentic qualities are ascribed only to the “exceptional” individuals and organizations, namely, institutional entrepreneurs (Beckert 1999; DiMaggio 1988,1991; Fligstein 1997; Garud, Hardy \& Maguire 2007; Greenwood \& Suddaby 2006), renegades (Kondra \& Hinings 1998) and outsiders (Greenwood, Suddaby \& Hinings 2002; Kraatz \& Moore 2002). These assumptions have led researchers to overlook the role of the majority of organizational members, who are arguably vital to institutional transmission because without their involvement, any institutional innovation would remain at the level of a plan, aspiration or ideal. In our view, this omission is problematic because an institutional template that is not enacted by the members of an organizational field would invariably fail to become an institution at all. This point has tended to be overlooked in the existing literature on institutional theory of diffusion (e.g., Abrahamson 1991; Gooderham, Nordhaug \& Ringdal 1999; Guler, Guillen \& Macpherson 2002; Ingram \& Simons 1995: 
O’Neill, Pouder \& Ruchholtz 1998; Strang \& Meyer 1993; Tolbert \& Zucker 1983). Due to its macro focus, this literature has few means for finely distinguishing between the tactics employed in making practices more "acceptable” (and thereby adoptable) to its recipients.

\section{Beyond Institutional Entrepreneurship}

To address these limitations and further our understanding of agency and institutional transmission, we offer a new set of theoretical instruments: distributed agency and dialogue.

\section{Distributed agency}

The concept of distributed agency helps to develop a more wide-reaching approach to agency, as pioneered by Zilber (2002), that also draws upon a wider tradition within organization studies that highlights the distributed nature of organizational phenomena, including: distributed entrepreneurial agency (Garud \& Karnøe 2003), distributed cognition (Hutchins 1995), distributed framing (Hardie \& Mackenzie 2007) and distributed leadership (Gronn 2002). Distributed agency implies the involvement, interaction and conjoint activity of multiple actors and reflects social structure and context, as they affect the distribution of agency throughout the system (cf. Giere and Moffatt (2003: 303) on distributed cognition). The concept is valuable for helping to move beyond the "structure/agency dualism", in which agency is either the result of changes to the structural relationship or the result of individual action (cf. Bennet, Wise, Wood \& Harvey (2003: 7) on distributed leadership).

We suggest that the term "institutional entrepreneurship" can be reserved to denote the framebreaking efforts of a few (individual and/or collective) actors involved in deliberate institution-building, whereas the term "distributed agency” can be used to reveal the more mundane and less prominent, but nevertheless essential, activities of "others” in the institutional work associated with emergent institutionbuilding (cf. Quack 2007: 659). To use the popular metaphor of the theatre (e.g., “actor", “front stage/back stage”, “script”), institutional entrepreneurship focuses on the leading actors, whereas distributed agency also pays attention to the rest of the cast, the "stage-hands" and other supporting 
members from "behind the scenes” (cf. Lawrence \& Suddaby 2006: 249), and last, but not the least, the audience.

\section{Dialogue}

Parallel to expanding the notion of agency to include distributed agency, we also suggest to "open up" the process of institutional transmission to incorporate dialogue. In accordance with the third-wave institutionalism, the concept of dialogue helps to restore the qualities of "fluidity", "plasticity" and "pliability" to the notions of institution and institutionalization (cf. Hirsch \& Boal 2000: 256). This means taking seriously the social interactions involved in transmission and the role of recipients in the construction of meaning around institutional change. This highlights the reciprocity involved in institutionalization and portrays institutional work as a collective endeavor accomplished by multiple actors and incorporating multiple inputs. This fits well with the companion concept of distributed agency, as both emphasize involvement of a wide range of actors. Dialogue implies a process whereby individuals generate a shared (but by no means identical and not necessarily consensual) understanding of a local situation through their interaction with other individuals (as well as with artefacts). It is this intersubjective engagement that gives institutionalization its fluidity - both in terms of being incessantly in motion and in terms of generating variation rather than perpetuating an invariant pattern.

The temporal and spatial context, or a local interaction "arena” (Lave 1988), is crucial to the understanding of dialogical processes. Hence, we draw on the situated action approach to cognition, which originated in the work of researchers affiliated in the 1980s with the Palo Alto Institute for Research on Learning, such as Lave, Suchman and Wenger (e.g., Lave \& Wenger 1991; Suchman 1987; Wenger 1998) and was popularized in organization studies by Brown and Duguid (1991). In contrast with the traditional focus of cognitive research on "inside-the-head" phenomena and the focus of "old" social cognition research on "thinking about social stimuli", the situated action approach to cognition stresses that 'humans do much of their thinking in a social context' (Schwarz 1998: 247, 251). Its proponents argue that 'cognitive activities should be understood primarily as interactions between agents 
and physical systems and with other people' (Greeno \& Moore 1993: 49). This view interprets cognitions as an interactive and collaborative process rather than an exclusively individual act (Levine, Resnick \& Higgins 1993: 586) and as a process necessarily situated relative to a local context, which includes people’s interrelations with one another and with artefacts (Lorenz 2001: 318).

While the concept of dialogue fits with the discourse approach in institutional analysis (Phillips \& Hardy 1997; Phillips, Lawrence \& Hardy 2000; Phillips, Lawrence \& Hardy 2004), it departs from the unity and coherence emphasized by the concept of narrative (which is currently the primary focus of discursive studies of institutions), by also revealing the potential for discord and dispersion. Our treatment of discourse here is therefore consonant with Green’s suggestion (2004; also cf. Boje, Oswick \& Ford 2004) that discourses do not necessarily conform to the dominant institutional template, but may frequently depart from it. It is these departures that provide the focal point of interest for our analysis. The concept of dialogue also resonates with the broader range of dialogic analyses of other organizational phenomena, such as learning (Oswick, Anthony, Keenoy, Mangham \& Grant 2000), change (Jabri 2004) and identity (Carlsen 2006). Together, the concepts of dialogue and distributed agency enrich our understanding by allowing for the complexity and multivocality that is, we suggest, typical of institutional transmission.

\section{Institutionalization through the Lens of Distributed Agency and Dialogue}

From our perspective, institutions are constantly "under construction” through a process of intersubjective dialogue, that is, dependent on the meanings embedded in the interpretive frames and embodied in the situated performances of actors (Goffman 1959,1967). Fine's (1996: 112) study of restaurant kitchens exemplifies this situatedness of social action: preparing a meal is not a stable, unchanging script, but may vary from being a profession, art, business or manual labor depending on 'when and if they seem appropriate' to the situation. Similarly, Creed, Scully and Austin (2002: 475) highlight the 'complexity and uncertainty of institutional reproduction' where reframing is done opportunistically by actors choosing between alternative frames, albeit driven by attachment to a master 
frame. From a situational perspective, agents can select from different institutional norms akin to the selection of different clothing. For instance, anti-gay groups can, paradoxically, adopt the gay rights discourse to argue for freedom from discrimination by gays (Creed et al 2002: 489), for example, when a non-gay person applies for a waiter position in a gay bar. Hence, given that the possibilities of practice cannot be anticipated by the templates, we need to focus on the "live" process whereby templates are enacted rather than the "lifeless" templates themselves (Seo \& Creed 2002).

\section{EMPIRICAL CASE: INSTITUTIONALIZING QUALITY IN BACK2WORK}

To illuminate our argument, we draw on the empirical data from a qualitative study of the introduction of a new information system in a UK public-private partnership organization called Back2Work (all names are pseudonyms). Back2Work delivers employment services in areas of high unemployment (known as 'Employment Zones') across the United Kingdom contracted from the UK government Department for Work and Pensions (hereafter DWP). In the first six years since the company was founded in 2000, it helped more than 70,000 people gain and maintain paid employment.

The study focused on the implementation of a new information system called 'Quality Framework' that was designed by Back2Work to improve the quality of the data supplied to the DWP about jobseekers (including information such as the number who have secured work and how long they maintain employment) in response to new contractual requirements established by the DWP in 2005. These contractual requirements reflect a wider shift towards accountability, evidence-based policy and "audit culture" (Strathern 2000) in the institutional field of public services, associated with the rise of New Public Management in the UK (and beyond) (Clarke \& Newman 1997; Hood 1998; Pollitt \& Bouckaert 2004).

Also relevant to understanding the case study is the context of the New Labour government's drive to create a new institutional model of public service delivery that is more innovative and responsive than traditional public bureaucracies (i.e. the government-run Job Centre) (Clarke, Newman, Smith, 
Vidler \& Westmarland 2007), including experimental modes of public-private (and voluntary) partnership (exemplified by Back2Work). From 2000 onwards, the contractual requirements from the DWP reflected the governmental policy focus on exploring the potential for innovation and responsiveness from the private and voluntary sectors. Accordingly, Back2Work, in the early years of operation, concentrated on 'getting results' as opposed to 'dotting Is and crossing Ts', in the words of one of its managers (Interview with Bob, Quality Framework Project Sponsor). The 2002 Back2Work Annual Report described the company as proud of its ability to 'cut through red tape and take risks'. As an example of an unorthodox solution to the problem of long-term unemployment, Back2Work arranged for a job seeker to have tattoo removal surgery on his face to increase his employability.

The more recent shift in emphasis towards 'evidence-based policy', where public policy and spending is tied to evidence of the impact and effectiveness of initiatives (such as comparing how many jobseekers find sustainable employment following help from public-private partnerships like Back2Work, versus the government-run Job Centre), led to a change in contractual requirements from the DWP. As the contract facilitator from the DWP explained to us:

Employment Zones came about, it was an idea that if we freed up the private and not-for-profit sector, could they do things better?... [but] it's got to be evidence-based policy... Whenever a piece of government policy comes into practice, there's always a team of statisticians and evaluators who will assess it over years... 'Did it work and can we measure how it worked?'

(Interview with Dave, Department for Work and Pensions contract facilitator)

Hence, a new set of contract requirements, tied to a system of incentives and penalties, were constructed in 2005 to encourage contractors to improve the quality of data held about jobseekers. Failure to meet the data quality targets would incur significant financial penalties and could ultimately result in losing the contract. In response, Back2Work designed Quality Framework with the aim to improve controls over the collection and storage of data about jobseekers. As noted by the senior business sponsor of the Quality Framework project at Back2Work: 
... there was a wake-up call to us to take a look at quality from a contract-compliant perspective... against the backcloth of increasing contractor requirements, very much around the detail of the delivery. It meant that we run the risk of losing contracts if we didn't act and didn't act fast.

(Interview with Bob, Quality Framework Project Sponsor)

As another senior manager explained:

... they [the DWP] are not only focusing on how many people we're getting into work, but they're focusing on the quality of the data that we export to them and the underpinning paperwork.

(Interview with Mary, Senior Manager)

In institutional theory terms, then, our case study can be understood as an example of institutional transmission of a new quality template, facilitated through forces of coercive isomorphism.

Coercive isomorphism, especially through direct imposition, presents a critical test for the "thirdwave institutionalism - and for our dialogical distributed agency account of institutionalization. Given the strong forces of coercive isomorphism in our case, we would expect to find top-down institutionalization par excellence, with rigid constraints on actors and action on the receiving end. Yet, as our analysis below shows, our study uncovered substantial room for creativity and reframing. It is important to note that the DWP data quality requirements did not mandate any particular solution and it was Back2Work's strategic choice to construct a technological solution in the form of a new information system (Quality Framework).

\section{METHODOLOGY}

\section{Data Collection}

This paper draws on one observational event from a wider qualitative study of Back2Work conducted between October 2005 and February 2006. The study was designed to combine semi-structured interviews with non-participant observation of day-to-day work activities, such as meetings, training 
sessions, client consultations and general "shadowing” of work activities, during the roll-out phase of the new Quality Framework information system. The data were collected using the following sources:

(1) thirty interviews between 15 and 90 minutes with organizational members, including senior management, information technology developers and suppliers, employment consultants and administrative employees, in nine different locations across the UK (including one supplier side);

(2) eighteen observations, including the observations of project meetings, information technology development meetings, training sessions, supplier meetings, troubleshooting meetings, project evaluation sessions and informal "shadowing” observations of everyday work activities across seven different locations across the UK (including one supplier site);

(3) twelve documents, including project briefs, project costing and planning documentation, meeting agendas, work process maps and training documents;

(4) numerous e-mail communications, where the researchers were copied into email exchanges relating to the change process.

Most of the interviews (24 out of 30) and some of the observations (8 out of 18) were recorded using a digital audio-recording device (where the presence of a recording device was permitted and not deemed too intrusive). Observations were written up in field-notes either in real-time or shortly after the event in cases where note taking would have interrupted the flow of interaction, such as informal conversations during coffee breaks.

The following analysis focuses on a training session for the staff in one of the Back2Work offices based in Birmingham in the Midlands. The training event provides an ideal site for exploring the institutionalization process because it represents a critical moment in translating templates from the broader institutional field (i.e., the Government and DWP) into the everyday practices of organizational members (i.e., the Back2Work employees and their clients). For example, training and awareness events are often where institutional innovations are first introduced and hence where the acceptability of the script is established and the meaning of a template is negotiated (e.g., "What is Quality Framework about?”, “What will it mean for me?”). The training event was chosen because it is representative of the 
broader findings of the study, which uncovered a general pattern of practices that dialogically reinterpreted the managerially-sanctioned quality template, as discussed in more detail below. Whilst other observations revealed similar processes, the event chosen exemplifies the sort of dialogue and distributed agency that, we suggest, accompany not only this case but also other cases of institutional transmission more generally. The event was also chosen because training sessions are likely to amplify these processes of dialogue and distributed agency, insofar as training sessions are often where organizational members first meet innovations, before their meaning becomes established and taken-for-granted (i.e., institutionalized).

\section{Data Analysis}

Data analysis was conducted with the aim of understanding 'meaning-making in vivo and in situ' (Zilber 2007: 1051). Qualitative research such as this is particularly well-suited to 'understand the actual production of meanings and concepts used by social actors in real settings' (Gephart 2004: 457). We deliberately analyze observational data from naturally-occurring events and interactions as opposed to relying on "texts" or interviews. While interviews are valuable sources of insight, they tend to elicit the reproduction of taken-for-granted "scripts" without investigating how they affect practice (Mueller \& Carter 2005: 241; Bergström \& Knights 2006: 355). Similarly, texts such as company documents, memos, manuals, etc. may be quite distanced from what actually happens in the field. Fieldwork observation was therefore central to our methodology because it enabled us to investigate what happens “on the ground” when institutions, such as the quality template in our case, travel over time and across different locales.

The first stage of data analysis involved transcribing the digital recording of the observation and typing up the accompanying hand-written field notes. Where notes had been written by more than one researcher, the accounts were cross-checked to produce a single record. It is important to note that the data-set was not "theory free" in the sense that decisions about what to collect and how to collect it were informed by the theoretical suppositions of the researchers (Bryman 1988; Bryman \& Burgess 1994; 
Hammersley \& Atkinson 1995). The analysis involved a process of “abduction”, i.e. a combination of induction and deduction. This means that we simultaneously moved upwards from the data and downwards from abstract theory in an iterative, back-and-forth process. This process was important because different theories enabled us to illuminate different parts of the data set or the same data in different ways. Our aim was to exploit, rather than eliminate, the tendency for research to be conducted through a particular “lens”, which involves ‘[adopting], either tacitly or explicitly, certain ways of seeing’ (Silverman 1993: 46).

By adopting an exploratory approach to data analysis (Bryman 1988; Silverman 1993), our aim was not to verify the validity, reliability or generality of particular accounts or interpretations. For example, we do not argue that the trainers in our analysis were "correct" and the audience "wrong” in how they made sense of the quality template. Rather, we examine how these various accounts (from interviews, observations, documents, etc.) played a role in negotiating, establishing and/or challenging the meaning of the quality template. Thus, our aim was to generate theoretical insight as opposed to establishing empirical generalizability from the data (Bryman 1988).

Furthermore, we have chosen the event analyzed in this paper (a training session) because it was typical of the findings of the study as a whole. For example, the study uncovered patterns of creative adaptation, deviation, reinterpretation and appropriation of the technology in other settings, including project meetings, trouble-shooting sessions and the day-to-day use of the new system. This variation occurred, we suggest, for a variety of practical reasons that were relative to the users' various contexts. For example, deviations and adaptations emerged as users attempted to make sense of the meaning of the artefact (e.g., “What changes should I make to my work routines to make this system work for me?”), contextualize the legitimacy of the artifact (e.g., “Why am I being asked to enter this information?”), adapt it to local practices (e.g., "We would prefer to do this differently"), minimize disruption to established work practices (e.g., "I don’t want to do all this extra work”) and establish an identity as a competent user and committed employee (e.g., "The back-log must be because the system is wrong, not me"). 
Our sample of data was also chosen to illustrate themes that have theoretical generality that is relevant to others interested in processes of institutionalization. While other situations would of course not be expected to replicate the exact same transmission mechanisms we identify below - for example, not every situation will involve distancing (see Table 1, section 1a) or appeals to self-interest (see Table 1, section 2a) as in our case - the finding that institutional templates are re-framed and modified through a process of distributed agency and dialogue is important for understanding processes of institutionalization more generally. For instance, it is reasonable to speculate that the "change champions" in our case would have drawn on a different set of transmission mechanisms if they had faced a different set of concerns from their audience (e.g., concerns that the proposed change would involve less work rather than more work for them, sparking worries about possible job losses), or if they had faced a different interaction “arena” (Lave 1988) altogether (e.g., a group of senior managers as opposed to administrative staff). These other scenarios, and indeed any other case where generic institutional templates meet specific local contexts, would also illustrate our thesis that institutionalization is not the product of the sole efforts of institutional entrepreneurs, but a collective accomplishment of all those involved (hence the term “distributed agency”). We will now turn to analyse the training event that comprises the focus of our analysis.

\section{ANALYSIS}

Our analysis focuses on a training session at a regional office of Back2Work. The purpose of the session was to introduce a new information system designed to improve the quality of the data about jobseekers supplied to the contractor, the UK government Department for Work and Pensions. Fourteen participants were present, including two researchers, ten administrative staff, the trainer Shirley and the IT representative Catherine. The trainer was in charge of the "soft", human relations side of the introduction of the quality initiative, and the IT representative was in charge of the "hard", technology side of the initiative. Note here that the change agents (the trainer and the IT representative) delivered what had 
already been translated into the language and realities of the organization. The principles of evidencebased policy and performance measurement had already been paraphrased from a generic New Public Management blueprint into a more context-specific template of the contractual requirements of the Department for Work and Pensions and further interpreted by the receiving organization, Back2Work, as an information system solution to the data quality problem. However, the process of institutionalization was still incomplete, as the staff of Back2Work had not yet embraced the new practices. Without their cooperation, the quality template would fail to be institutionalized. The training session was thus an important step towards the "bedding down" of the new practice - a crucial stage in its institutionalization.

Table 1 presents a series of extracts from the interaction between the trainers (Shirley and Catherine) and the audience (the employees targeted to change their practices). Two notes on our presentational style are needed here. First, for the purpose of grouping the extracts, the data is not presented in sequential order, but the time of each extract is instead marked. Second, while the themes we identify were prevalent throughout the whole session (seven hours of recording), in each section we have selected the verbatim quotes that best illustrate the theme in question.

\section{[ I nsert Table 1 around here]}

The findings presented in Table 1 show that we did not observe the process of diffusion of the quality template that we expected from such a tightly-coupled institutional field, with 'clearly legitimated organizational templates and highly articulated mechanisms ... for transmitting those templates to organizations within the sector' (Greenwood \& Hinings 1996: 1029). In this institutional context, we expected to find a linear process of diffusion, beginning with the strong coercive isomorphic mechanisms of the institutional context (i.e. the government's contractual requirements that mandated and enforced the new emphasis on data quality), translated into a new information system by senior management, then accepted by staff and incorporated into their working practices.

Table 1 shows that appeals to the institutional legitimacy of the quality template - both at a regulatory level from the DWP and at an organizational level from senior management - failed to 
establish the legitimacy of the template at a local level. The staff from the Midlands office demonstrated their agency in the form of resistance, cynicism and skepticism resulting from the clash between the template and their pre-existing local meanings, practices and agendas. For instance, the audience were resistant to the perceived increase in workload they anticipated from the introduction of the new template (see quote 2(a) iii.). Skepticism was also expressed about the viability of the new quality template, given their first-hand knowledge of the job they do (see quote 2(a) i.), and their preferred local practices and routines (see quote 3(c) ii.). Whilst skepticism or resistance are by no means unusual or unexpected responses (Putnam, Grant, Mickelson \& Cutcher 2005), in this particular context it occurred in spite of the legitimacy of the quality template from two institutional levels, from being mandated and enforced by the government department that provided the contract and from being sanctioned by senior management in Back2Work.

The agency of the audience led to a dialogue between the trainers and staff that we have grouped into three aspects: identity, interests and need for voice (see Table 1). This dialogue was designed to find creative methods of transmission to respond to the specific context in hand, or in Lave's (1988) terms, the local interaction “arena”, i.e. by responding to the specific concerns expressed by the staff of the Midlands office. This dialogue is significant for how it led to the deviation, adaptation and corruption of the received template. For instance, deviation from the template occurred when the trainers attempted to distance themselves from the "script" provided for them in an attempt to identify with the audience and construct a shared identity of "us" versus "them”" (see quotes 1(a) i. and 1(a) ii.). The dialogue also led to a recognition of the need for adaptation as a result of the audience's local knowledge of their job (see 3(a) i-iii) and the need to incorporate local practices and routines (see 3(c) i.-iv.). Finally, the template was corrupted as the trainers attempted to appeal to the sectional interests of their audience, for instance, by arguing that the new template would make their jobs easier and reduce their workload (see 2(a) i.-v.). By appealing to the audience's self-interest in this way, the institutional legitimacy of the template (i.e. we must do this because it is mandated by the DWP and sanctioned by management) was corrupted in an attempt to make the template more acceptable and palatable to the local audience. 
This transformation of the quality template, we suggest, demonstrates the distributed agency at play whereby the local concerns and meanings of the staff at the Midlands office become incorporated into the template during the dialogue that occurred in the training session. In other words, when the template met the agency of the Midlands staff in the form of skepticism and outright resistance, the change agents sought to enter into dialogue with their audience (as opposed to ignoring their concerns). In doing so, the template was altered to make it more "socially acceptable and credible” (Weick 1995: 61) to the audience, even if this also corrupted its original, institutionally-mandated and manageriallysanctioned meaning and led to unintended outcomes (Balogun \& Johnson 2005). As such, agency was not simply in the hands of the institutional entrepreneurs that envisaged the new quality requirements at the DWP or the senior managers in Back2Work that translated it into a new information system, but was also distributed across the organization, including those members at the bottom of the organizational hierarchy that comprised the "targets" of the new template. While the dialogue we observed deviated, adapted and corrupted the template, we suggest that this did not undermine, but rather facilitated, the transmission of the template. For instance, it is unlikely the quality template would become "habitualized” (Berger \& Luckman 1967) if the trainers simply reproduced the template (our findings show that this had clearly failed), and refused to recognize the agency of the audience by engaging in dialogue, leaving the audience remaining skeptical and resistant.

\section{DISCUSSION}

The findings of this study suggest that the transmission of institutions involves more than simple linear processes of diffusion but rather (a) an interactive and collaborative process that is (b) situated relative to a particular local context. We observed a distributed and dialogical process whereby agency was not in the hands of a few, but rather distributed amongst the many actors involved in the situation and relative to the context of interaction. Context is important to this process because different contexts, such as the project meetings attended by the system designers and senior management that we observed, involved a 
different set of interpretations that led to different sets of meanings about the quality template being constructed.

Our point of departure was the question: "What actually happens when coercive isomorphic pressures hit the ground, in this case the imposition of a quality template by a powerful government actor”? Given that Total Quality Management (TQM) has recently been described as past its “prime” and 'suffering from disillusionment and scepticism' even in the UK, with a renewed focus on its technical foundations, there is increased 'potential for customized applications' (David and Strang 2006: 231). By examining what happened during a specific training session we ask: "What does this customization look like”?

We found that implementation/diffusion of a template can be facilitated by (a) creating a positive sense of identity for the audience, whether this is a collective "we” and/or a sectional "them” and "us" (see Table 1, section 1.), (b) appealing to the interests of the audience, both at the level of collective interests and self-interests (see Table 1, section 2), and (c) making the audience feel that they have a voice and input in the transmission of the template (see Table 1, section 3). These are specific tactics that can be employed to help embed specific TQM practices into organization processes - an important issue given the widely held view that implementation failure is substantially due to the company and its local unit leaders not 'making TQM an integral part of their organizational unit’s practice and culture' (Beer 2003: 626). Our account goes beyond existing efforts by outlining the micro-context, where agents discursively allocate people voice, an identity or interests. The practical effect of these discursive activities is to successfully complete the training session, or indeed any other such activity in the transmission of a template, and thereby drive forward the implementation process.

By bringing voice, identity and interest creatively into play, the trainers responded to the difficulties that they seemed to encounter. What the examples we found have in common is their attempt to engage in dialogue with the meanings-in-construction by the audience and thereby increase their commitment to the implementation process. The concerns of the recipients were not simply ignored and “bull-dozed” over in a rigid imposition of a coercively-enforced template. This dialogue was achieved in 
various ways, as detailed in Table 1, such as by displaying sensitivity and respect for the voice of the audience, in this case by displaying recognition of the legitimacy of their concerns (see 3(a)) and by recognizing their rights to have voice (see 3(b)) and maintain local variations (see 3(c)). Second, the trainers also employed methods to transform (i.e. change) the meanings-under-construction in order to establish local legitimacy for the quality template and avoid a de-railing of the change process: for example, by distancing themselves from the idea that they are merely a "mouthpiece” of management (see 1(a) i.-ii.), by demonstrating their awareness of what the audience might want (see 2(a) i.-v.) and attempting to show empathy and solidarity with the audience (see 3(a) and (b)). This example of identity positioning, i.e. we are "one of you” and "on your side”, is an important finding because such subtle maneuvering is, in our view, crucial to the success of the session. This finding links to Fligstein's (1997) thesis that institutionalization is facilitated by the creative social skills required to "imaginatively identify” with others and Creed, Scully and Austin’s (2002) argument that effective legitimating accounts are those which enable recipients to identify with the message. For example, with regard to "identity", membership categorization devices are ways actors choose to describe themselves and others (Potter \& Wetherell 1987: 128-131), which carry with them social and moral implications (i.e. who is a member of what social group and what responsibilities, expectations, rights and obligations does their membership involve). For example, the term 'we' may be used to refer to 'our membership of the business' to infer a set of shared interests, responsibilities and objectives - namely, tackling the 'problem' of having "lost money" because of failed audits (see 1(b) i. and 2(b) i.-iii.). We show how membership categorization, such as use of the collective pro-noun "we", was used to try to construct a common identity and collective responsibility for ensuring the survival of the business. The trainers were almost certainly not expected to distance themselves from and criticize the script in order to create a sense of allegiance with the audience (see 1(a) i.). Indeed, a key finding from our analysis is that the dialogue led to a deviation from the institutionally-preferred meaning of the quality template. For instance, through creative dialogue around the interests of the audience, the trainers emphasized the potential improvements for the working lives of the audience (e.g., reducing their workload) (see 2(a) i.-v.), thereby potentially undermining the emphasis 
on protecting the interests of the organization and the coercive institutional pressures towards evidencebased policy in the New Public Management in the UK discussed above. In Suchman’s (1995) terms, the agents employed exchange action (a form of pragmatic legitimacy) when what was called for was procedural action, a form of moral legitimacy. For us, this deviance appears logical in this particular local context and given the dialogue that unfolded. It is also noteworthy that this "self interest" tactic was used as early as two minutes into the training session (see 1(a) i.). This suggests that the trainers tried to pre-empt and build-in local adaptations to the meaning of the template that would respond to the local context of deployment, as opposed to being a merely reactive, face-saving technique designed to "rescue" a bad situation (Goffman 1967) and "respond” to a resistant audience.

Two pertinent points need delineation at this point in time. First, we do not suggest that the training session is the only (or even the most important) event in the process of institutionalization of the quality template. While the training session is only one small part of the process of institutionalization, it is significant because it represents a critical juncture where the meaning of the quality template (e.g., What is it? How will it change my working practices? Why should I change my working practices?) is negotiated, and where its acceptance has to be achieved. In Zbaracki’s (1998: 612-626) “nested" Variation-Selection-Retention model, our study addresses retention at the micro level of a work unit. We recognize that this retention has to be continually established (e.g., in the refresher courses, troubleshooting sessions and project meetings we observed during the remainder of the project) until a template becomes taken-for-granted (Berger \& Luckman 1967: 53) or, in Beer’s (2003) metaphor, until the seed sinks into the soil. Our paper is an attempt to answer the call to research what actually happens "on the ground". Our argument is that the quality template did not simply arrive with ready-made legitimacy - we found that the institutional legitimacy of the DWP audit requirements, plus the managerial sanctioning of the change, was in fact rejected by the audience - but rather its legitimacy at the local level was actively “worked up” through creative and situationally-relevant dialogue between the “champions” and “recipients” (Phillips \& Hardy 1997; Selznick 1949). We agree with Suddaby (2009) that rhetorical strategies are a key mechanism for establishing legitimacy. Second, our argument does not 
imply the transmission methods we observed were always effective at ensuring acceptance and enactment of the quality template. For example, we did not interview the audience after the training event to investigate how the dialogue affected their attitudes to the change and their willingness to put the quality idea into practice. This would furthermore be inconsistent with our methodological approach, which views interviews as situated accounts rather than neutral windows into stable "attitudes" on the inside (Potter \& Wetherell 1987: 145-155, 163-165). What our study does reveal is the (discursive) practices of distributed agency and dialogue involved in the transmission of an institutional template.

\section{SUMMARY AND CONCLUSIONS}

In this paper we have addressed the question of what actually happens "on the ground" when attempts are made to implement an institutionally-demanded template. We have put forward the twin notions of distributed agency and dialogue in order to analyze the sort of interactional practices involved in implementation. These concepts, we suggest, answer the call for more research into 'institutional work', i.e. 'the broad category of purposive action aimed at creating, maintaining and disrupting institutions' (Lawrence \& Suddaby 2006: 216). Based on detailed analysis of a training session from a qualitative study in a UK public-private partnership, we highlight the forms of distributed agency and dialogue that we observed when a quality template was implemented through a series of discursive methods, namely around voice, identity and interest.

As far as our theoretical contributions are concerned, first and foremost, our study contributes to the opening up of 'the black box of diffusion', as urged by Lawrence and Suddaby (2006: 247) in a recent review of institutional research on organization. The discussions of institutional transmission to date have tended to: portray it as 'frictionless' and to 'gloss over... substantial institutional work on the part of organizational actors who must persuade others in their organizations of the merits of the innovation, experiment with the innovation in an effort to understand it and how it might apply to their own situations, modify it in order to gain internal legitimacy, and forge practical connections for the new 
structure or practice' (Lawrence \& Suddaby 2006: 247). In line with this, we draw attention to the sort of interactional dialogue employed by those involved in transmitting institutions, resulting from their creativity in responding to the agency of the recipients. Our study uncovered a dialogue around the voice, interest and identity of the audience designed to drive implementation forward and make the template more 'socially acceptable and credible' (Weick 1995: 61) and create a 'new negotiated group understanding' (Balogun \& Johnson, 2005: 1576). While this dialogue altered and questioned its institutionally sanctioned form, this is not a case of failed institutional transmission resulting from the unintended consequences that occurred when the quality template met the agency of local audiences. Indeed, a series of follow-up visits showed that the local office in question did indeed implement the new quality system and comply with the institutional pressures they faced, though with an element of “tinkering” with the details. Thus, our study shows how dialogue and distributed agency play a role in the successful transmission of institutional innovations, albeit in a modified form.

Second, our study enriches the picture of organizational responses to institutionalization (Oliver 1991). We suggest that we need to study the discursive processes, for instance during training sessions and other such embedding activities, which are involved in the gradual deepening or "entrenchment" of new practices (Zeitz, Mittal \& McAulay 1999: 743). In Zbaracki’s (1998) framework, such deepening would happen through the replication of the Variation-Selection-Retention spiral, albeit at lower levels and distributed throughout the organization. We argue that by granting voice to the audience, by acknowledging the right to local variation (polyphony), by taking account of their situated interests and by addressing and, potentially, re-shaping their identity concerns, a deeper form of adoption is being made possible, whereby the template can become more entrenched.

Third, Meyer and Rowan (1977: 341-2) had argued that, under certain circumstances, organizations establish loosely-coupled arrangements, where there is a gap between their 'blueprint for activities' and their actual work activities. Insofar as generalized rules might be seen as 'inappropriate to specific situations’ (Meyer \& Rowan 1977: 355), some form of de-coupling is likely to ensue. Instead of decoupling, we suggest that 'locally adaptive discursive strategies' (Creed et al 2002: 477) are an 
alternative or complementary path that might be taken. If discursive activities can make a template more convincing to potential adopters, this will therefore facilitate actual implementation.

Fourth we highlight that both the transformation and the reproduction of structures requires 'resourceful and innovative human conduct' (Sewell 1992: 27). Diffusion is hence more likely to involve 'reinterpretations than recitations' (Creed et al 2002: 476), making it a fundamentally idiosyncratic and

unpredictable process (Sewell 1992). Zbaracki (1998: 619), for example, found a quiet, skeptical response during the TQM selection process, where organization members were kind of 'coerced into participating in TQM' and, as a result, displayed a degree of dissonance. We have also built on and advanced the work of these authors by suggesting the concepts of dialogue and distributed agency, which enable us to understand the nature and consequences of modifications to institutional templates. For example, in our study the phrase 'we are just delivering this, we don't like it' (see Table 1, 1(a) i.) was an unexpected, creative method of conducting a training session that embodied both mimesis ('we're delivering this') and difference ('just', 'don’t like’). By viewing institutions as constantly and continuously "in the making”, our approach avoids a compartmentalized view of institutionalization, according to which institutional innovation and change is generated by mechanisms different from those that govern continuity and transmission of institutions. In contrast, by focusing on the ongoing processes of dialogue that create, contest and change institutions, we highlight the similarity between the forces involved in the creation and evolution of institutions.

\section{ACKNOWLEDGEMENTS}

The authors would like to thank the UK Economic and Social Research Council for funding the research upon which this article is based and Dr. Anita Mangan for research assistance in the collection and transcription of the data. 


\section{REFERENCES}

Abrahamson E (1991) Managerial fads and fashions: The diffusion and rejection of innovations, Academy of Management Review 16: 586-612.

Balogun J and Johnson G (2005) From intended strategies to unintended outcomes: The impact of change recipient sensemaking, Organizational Studies 26: 1573-1601.

Barley SR and Tolbert PS (1997) Institutionalization and structuration: Studying the links between action and institution, Organizational Studies 18: 93-117.

Beer MS (2003) Why Total Quality Management programs do not persist, Decision Sciences 4: 623-42.

Beckert J (1999) Agency, entrepreneurs and institutional change: The role of strategic choice and institutionalized practices in organizations, Organizational Studies 20: 777-799.

Bennet NC, Wise P, Wood J and Harvey A (2003) Distributed leadership, National College for School Leadership, accessed at http://www.ncsl.org.uk/mediastore/image2/bennett-distributedleadership-full.pdf on 19 February 2008.

Berger PL and Luckmann T (1967) The Social Construction of Reality: A Treatise in the Sociology of Knowledge, Anchor Books, New York.

Bergström O and Knights D (2006) Organizational discourse and subjectivity: Subjectification during processes of recruitment, Human Relations 59: 351-377.

Boje DM, Oswick C and Ford JD (2004) Language and organization: The doing of discourse, Academy of Management Review 29: 571-577.

Brint S and Karabel J (1991) The Diverted Dream: Community Colleges and the Promise of Educational Opportunity in America, 1900-1985, Oxford University Press, New York.

Brown JS and Duguid P (1991) Organizational learning and communities of practice: Toward unified view of working, learning and innovation, Organization Science 2(1): 40-57.

Bryman A (1988) Quantity and Quality in Social Research, Routledge, London.

Bryman A and Burgess RG (Eds) (1994) Analyzing Qualitative Data, Routledge, London.

Carlsen A (2006) Organizational becoming as dialogic imagination of practice: The case of the Indomitable Gauls, Organization Science 17: 133-149.

Clarke J and Newman J (1997) The Managerial State, Sage Publications, London.

Clarke J, Newman J, Smith N, Vidler E and Westmarland L (2007) Creating Citizen-Consumers. Changing Publics and Changing Public Services, Sage Publications, London.

Creed WED, Scully M and Austin JR (2002) Clothes make the person? The tailoring of legitimating accounts and the social construction of identity, Organization Science 13: 475-496. 
Dacin MT, Goodstein J and Scott WR (2002). Institutional theory and institutional change: Introduction to the Special Research Forum, Academy of Management Journal 45: 45-57.

David R and Strang D (2006) When fashion is fleeting: Transitory collective beliefs and the dynamics of TQM consulting, Academy of Management Journal 49: 215-33.

DiMaggio PJ (1988) Interest and agency in institutional theory, in Zucker LG (Ed) Institutional Patterns and Organizations: Culture and Environment, pp.3-12, Ballinger, Cambridge.

DiMaggio PJ (1991) Constructing an organizational field as a professional project: U.S. art museums, 1920-1940, in Powell WW and DiMaggio P (Eds) The New Institutionalism in Organizational Analysis, pp.267-292, University of Chicago Press, Chicago.

DiMaggio PJ and Powell WW (1983) The iron cage revisited: Institutional isomorphism and collective rationality in organizational fields, American Sociological Review 48: 147-160.

DiMaggio PJ and Powell WW (1991) Introduction, in Powell WW and DiMaggio P (Eds) The New Institutionalism in Organizational Analysis, pp.1-38, University of Chicago Press, Chicago.

Elsbach KD (2002) Intraorganizational institutions, in Baum JAC (Ed) The Blackwell Companion to Organizations, pp.37-57 Blackwell, Oxford.

Fine G (1996) Justifying work: Occupational rhetorics as resources in restaurant kitchens, Administrative Science Quarterly 41: 90-115.

Fligstein N (1997) Social skill and institutional theory, American Behavioral Scientist 40: 397-405.

Garud R, Hardy C and Maguire S (2007) Institutional entrepreneurship as embedded agency: An introduction to the Special Issue, Organizational Studies 28: 957-969.

Garud R and Karnøe P (2003) Bricolage versus breakthrough: Distributed and embedded agency in technology entrepreneurship, Research Policy 32: 277-300.

Gephart R (2004) Qualitative research and the Academy of Management Journal, Academy of Management Journal 47: 454-462.

Giere RN and Moffatt B (2003) Distributed cognition: Where the cognitive and the social merge, Social Studies of Science 33: 301-310.

Goffman E (1959) The Presentation of Self in Everyday Life, Anchor, Garden City, NY.

Goffman E (1967) Interaction Ritual, Pantheon, New York.

Gooderham PN, Nordhaug O and Ringdal K (1999) Institutional and rational determinants of organizational practices: Human resource management in European firms, Administrative Science Quarterly 44: 507-531.

Goodstein JD (1994) Institutional pressures and strategic responsiveness: Employer involvement in workfamily issues, Academy of Management Journal 37: 350-382.

Gouldner A (1954) Patterns of Industrial Bureaucracy, The Free Press, Glencoe, IL. 
Green S (2004) A rhetorical theory of diffusion, Academy of Management Review 29: 653-669.

Greeno . G and Moore JL (1993) Situativity and symbols: Response to Vera and Simon, Cognitive Science 17: 49-60.

Greenwood R and Hinings CR (1996) Understanding radical organizational change: Bringing together the old and the new institutionalism, Academy of Management Review 21: 1022-1054.

Greenwood R and Suddaby R (2006) Institutional entrepreneurship in mature fields: The Big Five accounting firms, Academy of Management Journal 49: 27-48.

Greenwood R, Suddaby R and Hinings CR (2002) Theorizing change: The role of professional associations in the transformation of institutionalized fields, Academy of Management Journal 45: 58-80.

Gronn P (2002) Distributed leadership, in Leithwood K, Hallinger P, Seashore-Louis K, Furman-Brown G, Gronn P, Mulford W and Riley K (Eds) Second International Handbook of Educational Leadership and Administration,pp. 653-696, Kluwer, Dordrecht.

Guler I, Guillen MF and Macpherson JM (2002) Global competition, institutions, and the diffusion of organizational practices: The international spread of ISO 9000 quality certificates, Administrative Science Quarterly 47: 207-232.

Hammersley MP and Atkinson P (1995) Ethnography: Principles in Practice $2^{\text {nd }}$ edn. Routledge, London.

Hardie I and Mackenzie D (2007) Constructing the market frame: Distributed cognition and distributed framing in financial markets, New Political Economy 12: 389-403.

Hasselbladh H and Kallinikos J (2000) The project of rationalization: A critique and reappraisal of neoinstitutionalism in organization studies, Organization Studies 21: 697-720.

Heugens PPMAR and Lander MW (2007) Testing the strength of the iron cage: A meta-analysis of neoinstitutional theory. Report Series ERS-2007-007-ORG, Erasmus Institute of Research on Management, accessed at www.erim.eur.nl on 4 February 2008.

Hirsch PM (1997) Review essay. Sociology without social structure: Neo-institutional theory meets brave new world, American Journal of Sociology 102: 1702-1723.

Hirsch PM and Boal KB (2000) Whose social construction? Berger and Luckmann revisited, Journal of Management Inquiry 9: 256-257.

Hirsch PM and Lounsbury M (1997) Ending the family quarrel: Toward a reconciliation of "old” and "new" institutionalism, American Behavioral Scientist 40: 406-418.

Hood C (1998) The Art of the State: Culture, Rhetoric and Public Management, Clarendon Press, Oxford.

Hutchins E (1995) Cognition in the Wild, MIT Press, Cambridge.

Ingram PT, Simons T (1995) Institutional and resource dependence determinants of responsiveness to work-family issues, Academy of Management Journal 38: 1466-1482. 
Jabri M (2004) Change as shifting identities: a dialogic perspective, Journal of Organizational Change Management 17: 566-77.

Kondra AZ and Hinings CR (1998) Organizational diversity and change in institutional theory, Organizational Studies 19: 743-767.

Kraatz MS and Moore JH (2002) Executive migration and institutional change, Academy of Management Journal 45: 120-143.

Lave J (1988) Cognition in Practice: Mind, Mathematics, and Culture in Everyday Life, Cambridge University Press, Cambridge.

Lave J and Wenger E (1991) Situated Learning: Legitimate Peripheral Participation, Cambridge University Press, Cambridge.

Lawrence TB and Suddaby R (2006) Institutions and institutional work, in Clegg S, Hardy, C, Lawrence, $\mathrm{T}$ and Nord WR (Eds) The SAGE Handbook of Organization Studies $2^{\text {nd }}$ edn, 2: 215-254, Sage Publications, London.

Levine JM, Resnick LB and Higgins ET (1993) Social foundations of cognition, Annual Review of Psychology 44: 585-613.

Lorenz E (2001) Models of cognition, the contextualisation of knowledge, and organisational theory, Journal of Management and Governance 5: 307-330.

Meyer JW and Rowan B (1977) Institutionalized organizations: Formal structure as myth and ceremony, American Journal of Sociology 83: 340-363.

Mizruchi MS and Fein LC (1999) The social construction of organizational knowledge: A study of the uses of coercive, mimetic, and normative isomorphism, Administrative Science Quarterly 44: 653-683.

Mueller F and Carter C (2005). The scripting of Total Quality Management within its organizational biography, Organizational Studies 26: 219-245.

Oliver C (1991) Strategic responses to institutional processes, Academy of Management Review 16: 145179.

O'Neill H, Pouder R and Ruchholtz A (1998) Patterns in the diffusion of strategies across organizations: Insights from the innovation diffusion literature, Academy of Management Review 32: 98-114.

Oswick C, Anthony P, Keenoy T, Mangham I and Grant D (2000) A dialogic analysis of organizational learning, Journal of Management Studies 37: 887-901.

Palmer DA and Biggart NW (2002) Organizational institutions, in Baum JAC (Ed) The Blackwell Companion to Organizations, pp.259-280, Blackwell, Oxford.

Phillips N and Hardy C (1997) Managing multiple identity: Discourse, legitimacy and resources in the UK refugee system, Organization 4: 159-185. 
Phillips N, Lawrence TB and Hardy C (2000) Interorganizational collaboration and the dynamics of institutional fields, Journal of Management Studies 37: 23-43.

Phillips N, Lawrence TB and Hardy C (2004) Discourse and institutions, Academy of Management Review 29: 635-652

Pollitt C and Bouckaert C (2004) Public Management reform: A Comparative Analysis $2^{\text {nd }}$ edn. Oxford University Press, Oxford.

Potter J and Wetherell M (1987) Discourse and Social Psychology: Beyond Attitudes and Behaviour, Sage Publications, London.

Putnam LL, Grant D, Mickelson G and Cutcher L (2005) Discourse and resistance: Targets, practices and consequences, Management Communication Quarterly 19: 5-18.

Quack S (2007) Legal professionals and transnational law-making: A case of distributed agency, Organization 14: 643-666.

Schwarz N (1998) Warmer and more social: Recent developments in cognitive social psychology. Annual Review of Sociology 24: 239-264.

Scott WR (2001) Institutions and Organizations $2^{\text {nd }}$ edn. Sage Publications, Thousand Oaks.

Selznick P (1949) TVA and the Grass Roots, University of California Press, Berkeley.

Selznick P (1996) Institutionalism “old” and “new”, Administrative Science Quarterly 41: 270-277.

Seo M-G and Creed WED (2002) Institutional contradictions, praxis, and institutional change: A dialectical perspective, Academy of Management Review 27: 222-247.

Sewell WH (1992) A theory of structure: Duality, agency, and transformation, American Journal of Sociology 98: 1-29.

Silverman D (1993) Interpreting Qualitative Data: Methods for Analysing Talk, Text and Interaction, Sage Publications, London.

Stinchcombe A (1997) On the virtues of the old institutionalism, Annual Review of Sociology, 23: 1-18.

Strang D and Meyer JW (1993) Institutional conditions for diffusion, Theory and Society 22: 487-511.

Strang D and Soule SA (1998) Diffusion in organizations and social movements: From hybrid corn to poison pills, Annual Review of Sociology 24: 265-290.

Strathern M (Ed) (2000) Audit Cultures: Anthropological Studies in Accountability, Ethics and the Academy, London, Routledge.

Suchman L (1987) Plans and Situated Actions: The Problem of Human-Machine Communication, Cambridge University Press, Cambridge.

Suchman MC (1995) Managing legitimacy: Strategic and institutional approaches, Academy of Management Review 20: 571-610. 
Tolbert PS and Zucker LG (1983) Institutional sources of change in the formal structure of organizations: The diffusion of civil service reform, 1880-1935, Administrative Science Quarterly 28: 22-39.

Weick KE (1995) Sensemaking in Organizations, Sage Publishing, London.

Wenger E (1998) Communities of Practice: Learning, Meaning and Identity, Cambridge University Press, Cambridge.

Zald MN (1970) Political economy: A framework for comparative analysis, in Zald MN (Ed) Power in Organizations, pp. 221-262, Vanderbilt University Press, Nashville, TN.

Zbaracki MJ (1998) The rhetoric and reality of total quality management, Administrative Science Quarterly, 43: 602-636.

Zeitz G, Mittal V and McAulay B (1999) Distinguishing adoption and entrenchment of management practices: A framework for analysis, Organizational Studies 20: 741-776.

Zilber TB (2002) Institutionalization as interplay between actions, meanings and actors: The case of a rape crisis center in Israel, Academy of Management Journal 45: 234-254.

Zilber TB (2007) Stories and the discursive dynamics of institutional entrepreneurship: The case of Israeli high-tech after the bubble, Organizational Studies 28: 1035-1054.

Zucker LG and Darby MR (1997) Individual actions and the demands for institutions, American Behavioral Scientist 40: 502-513. 
Table 1. Enacting Distributed Agency through Dialogue in Back2Work

\begin{tabular}{|c|c|c|c|c|}
\hline $\begin{array}{l}\text { Distributed } \\
\text { agency }\end{array}$ & Dialogical devices & & & Examples \\
\hline \multirow[t]{3}{*}{$\begin{array}{l}\text { 1. Identity } \\
\text { (who) } \\
\text { Constructing } \\
\text { a sense of } \\
\text { who the } \\
\text { audience are }\end{array}$} & \multirow{2}{*}{$\begin{array}{l}\text { (a) Distancing the change champions } \\
\text { from the officially sanctioned script, } \\
\text { by showing that they are not } \\
\text { "puppets", that it is OK to question } \\
\text { and criticize the script, that they are } \\
\text { all "in the same boat", and the } \\
\text { trainers are "on their side", thereby } \\
\text { creating an "us" and "them" }\end{array}$} & i $\quad(12 \mathrm{~min})$. & $\begin{array}{l}\text { Catherine: } \\
\text { Shirley: }\end{array}$ & $\begin{array}{l}\text { [reading from screen] "Performance Manager } \\
\text { interrogates.” We have an issue with that word, Catherine } \\
\text { and I. } \\
\text { Yeah, we don't like “interrogates”. We didn't put these } \\
\text { together. [Laughter] } \\
\text { We're just delivering this. We don't like it. }\end{array}$ \\
\hline & & ii $\quad$ (39 min.) & Shirley: & $\begin{array}{l}\text { We're bound to get resilience, but this isn't a Shirley and } \\
\text { Catherine thing, we're just delivering this. }\end{array}$ \\
\hline & $\begin{array}{l}\text { (b) Establishing a sense of collective } \\
\text { identity through the membership } \\
\text { categorization term "we" }\end{array}$ & i $\quad(2$ min. $)$ & Shirley: & $\begin{array}{l}\text { We know ... as a business that we've made errors. OK? } \\
\text { We're over five years old now and unfortunately as a } \\
\text { business we've also lost money because our audit has not } \\
\text { been hundred percent. But the Quality Framework has } \\
\text { been introduced to try and eliminate all of that... }\end{array}$ \\
\hline
\end{tabular}


Table 1. Enacting Distributed Agency through Dialogue in Back2Work [continued]

\begin{tabular}{|c|c|c|c|c|c|}
\hline $\begin{array}{l}\text { Distributed } \\
\text { agency }\end{array}$ & Dialogical devices & & & & Examples \\
\hline \multirow{7}{*}{$\begin{array}{l}\text { 2. Interest } \\
\text { (why) } \\
\text { Articulating } \\
\text { why the } \\
\text { audience } \\
\text { should accept } \\
\text { the new } \\
\text { quality } \\
\text { template. }\end{array}$} & \multirow[t]{7}{*}{$\begin{array}{l}\text { (a) Emphasizing } \\
\text { self-interest (e.g., } \\
\text { making their job } \\
\text { easier) }\end{array}$} & $\mathrm{i}$ & (2 min.) & Shirley: & $\begin{array}{l}\text { You guys, I'm pretty confident, are going to buy into this today because it's } \\
\text { going to make your job a little bit easier, ok? I can hear Karen now going } \\
\text { 'Yes!' I can. I can hear her. I'd like you to physically say it at some point } \\
\text { today when we introduce it. It's going to make you guys, your job, a lot } \\
\text { easier with your communication with our consultants. }\end{array}$ \\
\hline & & ii & (11 min.) & $\begin{array}{l}\text { Sue: } \\
\text { Catherine: }\end{array}$ & $\begin{array}{l}\text { [This isn't going to work because Job Centres often fail to send us the } \\
\text { paperwork]... so that's gonna be a little bit of a problem for us. } \\
\text { You'll be able to see what jobcentres are getting things in on time and } \\
\text { which ones aren't, and you can use that to negotiate with the jobcentres that } \\
\text { aren't getting it in on time. .... It helps to keep track of what's where and } \\
\text { how long it's taking. }\end{array}$ \\
\hline & & iii & (39 min.) & ?: & $\begin{array}{l}\text { So we're gonna have to go into every record and check whether it's ok? So } \\
\text { that's gonna be extra work. }\end{array}$ \\
\hline & & & & ?: & $\begin{array}{l}\text { So technically this means that we're gonna be doing more work and the } \\
\text { consultants are gonna be doing less. }\end{array}$ \\
\hline & & & & Shirley: & $\begin{array}{l}\text { But it's all about quality isn't it, and getting things right first time. ... But } \\
\text { it's all to do with an ongoing audit isn't it. So when it comes to audit time - } \\
\text { you guys aren't sat here doing all the paperwork. }\end{array}$ \\
\hline & & iv & (66 min.) & Shirley: & $\begin{array}{l}\text { It's going to stop you going over to [colleagues] going “you've not done } \\
\text { that right". Communication is going to be better because there'll be more } \\
\text { efficiency on the system. }\end{array}$ \\
\hline & & & (72 min.) & Shirley: & $\begin{array}{l}\text { But eventually, come audit time, you guys aren't gonna have to do the } \\
\text { running around that you normally have to do because this is ongoing audit. } \\
\text { Now, I haven't got that scripted that's just from me. You know, that's just } \\
\text { something I thought. }\end{array}$ \\
\hline
\end{tabular}




\section{Table 1. Enacting Distributed Agency through Dialogue in Back2Work [continued]}

\begin{tabular}{|c|c|c|c|c|c|}
\hline Distributed & Dialogical devices & & & & Examples \\
\hline \multirow{3}{*}{$\begin{array}{l}\text { 2. Interest } \\
\text { (why) } \\
\text { [continued] }\end{array}$} & \multirow{3}{*}{$\begin{array}{l}\text { (b) Focusing on } \\
\text { collective interest, } \\
\text { by appealing to } \\
\text { their sense of duty } \\
\text { and obligation to } \\
\text { the business (e.g., } \\
\text { to ensure the } \\
\text { survival of the } \\
\text { business) }\end{array}$} & $\mathrm{i}$ & (11 min.) & Shirley: & $\begin{array}{l}\text {... this is the official process map and it's all in accordance with the, am, } \\
\text { DWP audit requirements as well. So it's quite clear that it has to be done }\end{array}$ \\
\hline & & ii & (45 min.) & $\begin{array}{l}\text { Shirley } \\
\text { Catherine: } \\
\text { Shirley }\end{array}$ & $\begin{array}{l}\text { You may already be aware, the new quality targets }-\ldots \text { if you have one } \\
\text { person overstay for one day on Stage } 1 \text {, that }- \text { you have a black mark } \\
\text { against your name for that quarter.... } \\
\ldots \text { it's like a penalty... } \\
\ldots \text { In the third quarter, if he's not rectified, you're over-staying and ... } \\
\text { there's a possibility of you losing your contract. } \\
98 \text { or } 99 \% \text { is no good. It's got to be } 100 \% \text { or the contract is under threat. }\end{array}$ \\
\hline & & iii & (73 min.) & Shirley: & $\begin{array}{l}\text { 'Quality equals audit equals get paid'. At the end of the day that's what it's } \\
\text { all about, isn't it, that we pass the audit. }\end{array}$ \\
\hline
\end{tabular}


Table 1. Enacting Distributed Agency through Dialogue in Back2Work [continued]

\begin{tabular}{|c|c|c|c|c|c|}
\hline Distributed & Dialogical devices & & & & Examples \\
\hline \multirow{7}{*}{$\begin{array}{l}\text { 3. Voice } \\
\text { (what/how) } \\
\text { Recognizing } \\
\text { the audience's } \\
\text { need for input } \\
\text { into what } \\
\text { changes the } \\
\text { new template } \\
\text { involves and } \\
\text { how it should } \\
\text { be } \\
\text { implemented. }\end{array}$} & \multirow{3}{*}{$\begin{array}{l}\text { (a) Acknowledging } \\
\text { the validity of their } \\
\text { claims }\end{array}$} & $\mathrm{i}$ & (40 min.) & Shirley: & $\begin{array}{l}\text { I do take your point.... Particularly if it takes you half an hour to do the ER } \\
\text { payments }\end{array}$ \\
\hline & & ii & $(40 \mathrm{~min})$. & Shirley: & I do take your point. I do understand what you mean there \\
\hline & & $\mathrm{iii}$ & (42 min.) & Shirley: & $\begin{array}{l}\text { We certainly take your point [sighs]. We're delivering Quality Framework as } \\
\text { best as we can today, I promise! }\end{array}$ \\
\hline & \multirow{4}{*}{$\begin{array}{l}\text { (b) Displaying } \\
\text { commitment to acting } \\
\text { upon local issues }\end{array}$} & i & $(18 \min )$. & Shirley: & $\begin{array}{l}\text { We need to take this back to the Business Quality Team and sort of lot it on a } \\
\text { national level }\end{array}$ \\
\hline & & ii & $(24 \min )$. & Shirley: & $\begin{array}{l}\text { OK, loads of things have been coming up and that's what we're trying to } \\
\text { encourage, because, as you know, the input process, little questions like that, } \\
\text { make an absolute difference [inaudible]. That isn't the final process map } \\
\text { [inaudible], so if something doesn't sit tight or you're not sure, do say, } \\
\text { because we need to log it and obviously try and get the system right } \\
\text { [inaudible] }\end{array}$ \\
\hline & & iii & $(27 \min )$. & Shirley: & $\begin{array}{l}\text { We just had a recent update on all the questions asked and that's one of the } \\
\text { common questions that's come through [inaudible]... OK, so thanks for that. } \\
\text { We'll question that back to our Quality Team and Business Process Team }\end{array}$ \\
\hline & & iv & (42 min.) & Shirley: & We're gonna log all this down and feed all this back \\
\hline
\end{tabular}


Table 1. Enacting Distributed Agency through Dialogue in Back2Work [continued]

\begin{tabular}{|c|c|c|c|c|c|}
\hline $\begin{array}{c}\text { Distributed } \\
\text { agency }\end{array}$ & $\begin{array}{c}\text { Dialogical } \\
\text { devices }\end{array}$ & & & & Examples \\
\hline \multirow[t]{4}{*}{$\begin{array}{l}\text { 3. Voice } \\
\text { (what/how) } \\
\text { [continued] }\end{array}$} & \multirow{4}{*}{$\begin{array}{l}\text { (c) Recognizing } \\
\text { the need for } \\
\text { adaptation to the } \\
\text { local context }\end{array}$} & $\mathrm{i}$ & (9 min.) & Shirley: & $\begin{array}{l}\text { We've got to do a generic process map clearly, OK? But obviously we do } \\
\text { appreciate that there's local systems, so if at any point that needs to be } \\
\text { [inaudible], we'll jot that down for you. }\end{array}$ \\
\hline & & ii & (13 min.) & $\begin{array}{l}\text { Sue: } \\
\text { Shirley: }\end{array}$ & $\begin{array}{l}\text { [inaudible] one person every day. I can't see that working } \\
\text { How you run your team is unique to every EZ location, which, I think, is } \\
\text { clearly probably why we're getting a bit of resistance here }\end{array}$ \\
\hline & & iii & (18 min.) & Shirley: & $\begin{array}{l}\text { This is not the first time this has come up because this is how things have got } \\
\text { to be done. You say: "Hang on a minute, we don't actually work like that } \\
\text { locally." We need to take this back to the Business Quality Team and sort of } \\
\text { lot it on a national level }\end{array}$ \\
\hline & & iv & (24 min.) & Catherine: & $\begin{array}{l}\text { What's happening is that, since everybody's been rolled out, notes like this } \\
\text { have been taken at the event, and we're sitting down and we'll, we'll get } \\
\text { answers to them all and put a new set f process maps through, if needs be, or } \\
\text { change in IT, if it needs be. So it's, sort of, like that, an ongoing } \\
\text { development. }\end{array}$ \\
\hline
\end{tabular}

